\title{
Low prevalence of Barrett's esophagus in a risk area for esophageal cancer in South of Brazil
}

\author{
Diego Michelon DE CARLI' ${ }^{1}$ Amanda Faria de ARAUJO² and Renato Borges FAGUNDES $1,2,3,4$
}

Received 31/5/2017 Accepted 4/7/2017

\begin{abstract}
Background - Barrett's esophagus a complication of gastroesophageal reflux disease (GERD) is a precursor of esophageal adenocarcinoma. The incidence of esophageal adenocarcinoma has been increasing in most Western countries. Rio Grande do Sul (RS), the Southernmost state of Brazil has the highest rates of esophageal cancer with low prevalence of esophageal adenocarcinoma. Objective - To investigate the prevalence of Barrett's esophagus among patients underwent to upper gastrointestinal endoscopy in the last 5 years. Methods -The records of patients underwent upper gastrointestinal endoscopy between 2011 and 2015 were analyzed. Demographic data, GERD symptoms, endoscopic findings, extension and histological diagnosis of columnar epithelia of the esophagus were recorded. Significance among the variables was accessed by chi-square test and Fisher's exact test with $95 \%$ CI. Results - A total of 5996 patients underwent to upper gastrointestinal endoscopy in the period were included. A total of $1769(30 \%)$ patients with GERD symptoms or esophagitis and $107(1.8 \%)$ with columnar lined esophagus were identified. Except for eight patients, the others with columnar lined esophagus had GERD symptoms or esophagitis. Barrett's esophagus defined by the presence of intestinal metaplasia occurred in 47 patients; 20 (43\%) with segments over $3 \mathrm{~cm}$ and $27(57 \%)$ with segments shorter than $3 \mathrm{~cm}$. The global prevalence of Barrett's esophagus was $0.7 \%$ and in GERD patients $2.7 \%$. The odds ratio for the occurrence of columnar lined esophagus in patients with GERD was $30(95 \% \mathrm{CI}=15.37-63.34)$. The odds ratio for the presence of intestinal metaplasia in long segments was $8(95 \% \mathrm{CI}=2.83-23.21)$. Conclusion $-\mathrm{GERD}$ patients had a risk 30 -folds greater to present columnar lined esophagus than patients without GERD symptoms. Long segments of columnar lined esophagus, had a risk eight-folds higher to have Barrett's esophagus than short segments. Barrett's esophagus overall prevalence was 0.7\%. In GERD patients, the prevalence was $2.7 \%$. Long Barrett's esophagus represented globally $0.3 \%$ and $1.1 \%$ in GERD patients.
\end{abstract}

HEADINGS - Barrett esophagus. Epithelial Cells. Esophageal neoplasms. Metaplasia. Intestinal neoplasms. Gastroesophageal reflux.

\section{INTRODUCTION}

Barrett's esophagus (BE) is a complication o gastroesophageal reflux disease (GERD) characterized by the replacement of squamous epithelium of the distal esophagus with columnar epithelium ${ }^{(13)}$. Diagnostic criteria for BE all over the world, except in the Great Britain and Japan, include the presence of intestinal metaplasia with goblet cells ${ }^{(1)}$. Barrett's esophagus is considered a precursor of esophageal adenocarcinoma which incidence has been increasing in the last years, mainly in the USA, Europe, and $\mathrm{Asia}^{(8,14,16,22)}$.

Rio Grande do Sul (RS), the southernmost state of Brazil has the highest rates of esophageal cancer in the country. Squamous cell carcinoma is the main histological type, while adenocarcinoma prevalence is $\operatorname{low}^{(9)}$. On the other hand, despite RS shows a high prevalence of GERD symptoms ${ }^{(15)}$, data on the occurrence of BE is scarce. There is only one study that identified intestinal metaplasia in the distal esophagus in $29 \%$ of the patients underwent upper gastrointestinal (GI) endoscopy ${ }^{(7)}$.

The aim of this study was to investigate the prevalence of columnar-lined esophagus (CLE) among patients who underwent to upper GI endoscopy in a reference center of the central region of $\mathrm{RS}$ in the last five years and estimate the prevalence of $\mathrm{BE}$ (columnar epithelium with intestinal metaplasia) in this area.

\section{METHODS}

The records of patients who underwent upper GI endoscopy between January 2011 to December 2015 at Hospital Universitário de Santa Maria (HUSM) were analyzed. HUSM is a reference center for the central region of RS State, covering 45 cities and approximately 1.2 million people. Gender, age, and clinical symptoms of GERD (heartburn and acid regurgitation) were computed. In the endoscopy records, a search for the diagnosis of hiatal hernia, esophagitis, and columnar-appearing esophagus was made. For the esophagus columnar-appearing, the extension and the histological diagnosis was registered. Incomplete or duplicate records were excluded. The records of patients submitted to an endoscopy for upper GI bleeding or endoscopic procedures like percutaneous endoscopic gastrostomy, endoscopic treatment of esophageal varices, esophageal strictures or achalasia dilatations were excluded too. The data was analyzed with SPSS 20 (IBM SPSS Statistics for Windows, Version 20.0. Armonk, NY: IBM Corp). Qualitative variables using absolute and relative frequencies and the mean and standard deviation to report quantitative variables were described. The significance between variables using qui-square or Fisher exact test when appropriate, at a significance level of $P<0.05$ was made. All procedures were made according to the ethical standards specified in Helsinki declaration. The Institutional Review Board approved the study protocol.

Declared conflict of interest of all authors: none

Disclosure of funding: no funding received

${ }^{1}$ Serviço de Gastroenterologia, Hospital Universitário, Universidade Federal de Santa Maria, RS, Brasil; ${ }^{2}$ Departamento de Clínica Médica, Universidade Federal de Santa Maria, RS, Brasil ${ }^{3}$ Programa de Pós-Graduação em Ciências da Saúde, Universidade Federal de Santa Maria, RS, Brasil; ${ }^{4}$ Programa de Pós-Graduação em Ciências em Gastroenterologia e Hepatologia, Universidade Federal do Rio Grande do Sul, RS, Brasil.

Correspondence: Renato Borges Fagundes. Avenida Grécia 1000, ap 1002, torre B - CEP: 91350-070 - Porto Alegre, RS, Brasil. E-mail: fagundesrb@gmail.com 


\section{RESULTS}

A total of 5996 patients were eligible for the study. Among them, were found 112 patients with the endoscopic diagnosis of a columnar-appearing esophagus. In five of these patients the histological diagnosis showed squamous epithelium, thus they were excluded from the analysis. Table 1 displays the histological diagnosis related to the extension of CLE of the remaining 107 (1.8\%) patients. A total of $1769(30 \%)$ patients with GERD symptoms or esophagitis were identified. Among patients with CLE, only eight did not present GERD symptoms or esophagitis. The mean age of GERD patients was $56.35( \pm 15.22)$ years, and $59 \%$ were female. Non-GERD patients had a mean age of $47.62( \pm 10.21)$ years, $50 \%$ female. The extension of CLE ranged from 0.5 to $14 \mathrm{~cm}$. The frequency of CLE in patients without GERD was $0.13 \%$, and it occurred in segments less than $1.0 \mathrm{~cm}$. BE occurred in 47 patients who represented $44 \%$ of the patients with CLE. The global prevalence of CLE was $1.7 \%$, and its prevalence in GERD patients was $5.6 \%$. The overall prevalence of $\mathrm{BE}$ was $0.7 \%$ whereas in GERD patients it was $2.7 \%$. The odds ratio for the occurrence of CLE in patients with GERD was 30 (CI95\% $=15.37-63.34$ ). The odds ratio for the presence of $\mathrm{BE}$ in long segments was $8(\mathrm{CI} 95 \%=2.83-23.21)$. Patients with long BE represented $0.3 \%$ overall and $1.1 \%$ of GERD patients. A significant association of CLE with GERD symptoms $(P=0.04)$ was identified in contrast with no association with age $(P=0.18)$, genre $(P=0.77)$, esophagitis $(P=0.50)$ or hiatal hernia $(P=0.1)$.

TABLE 1 . Histological findings in the patients with columnar lined esophagus by the extent of the CLE $(n=107)$

\begin{tabular}{lcc}
\hline Histological diagnosis & \multicolumn{2}{c}{ Extension of CLE } \\
\hline Fundic epithelium & $2(2 \%)$ & $0(0 \%)$ \\
Cardiac epithelium & $34(42 \%)$ & $3(3 \%)$ \\
Columnar epithelium without IM & $19(23 \%)$ & $2(2 \%)$ \\
$\begin{array}{l}\text { Columnar epithelium with intestinal } \\
\text { metaplasia (BE) }\end{array}$ & $27(33 \%)$ & $20(18 \%)$ \\
Total & $82(77 \%)$ & $25(23 \%)$ \\
\hline
\end{tabular}

CLE: columnar-lined esophagus; IM: intestinal metaplasia; BE: Barrett's esophagus.

\section{DISCUSSION}

In a five-years period, the records of inhabitants of a risk area for esophageal cancer, who underwent upper GI endoscopy were analyzed. CLE was identified in $1.7 \%$ of the population sample. The frequency of CLE in GERD patients was 5.6\% and in patients without GERD was $0.13 \%$. BE occurred in less than half of patients with CLE, presenting an overall prevalence of $0.7 \%$ and $2.7 \%$ in GERD patients.

These findings disagree with the previous report in the same area that identified $29 \%$ of patients underwent upper GI endoscopy presenting intestinal metaplasia in the distal esophagus ${ }^{(7)}$. The differences between these studies can be explained by their small sample (97 patients) and the finding of only short segments with less than three centimeters. They also did not find differences between patients with or without GERD symptoms. Probably the results of this larger sample reflect with more accuracy what happen in this population. On the other hand, these results are in parallel with others developed in Brazilian states even with smaller samples ${ }^{(2,12)}$.
They are also comparable with the rates reported from other countries ${ }^{(10,16,19,21)}$ including those countries where adenocarcinoma is the predominant histological type of esophageal cancer.

CLE is considered a marker for GERD. The distance between the most proximal and most distal esophageal biopsies positive for CLE define the length of the esophageal segment injured by reflux leading us to the concept of the squamous-oxyntic gap. The probability of the occurrence of intestinal metaplasia has been reported to be directly proportional to the length of the squamousoxyntic gap ${ }^{(4)}$. Our findings comply with these statements. GERD patients presented a risk 30 -folds greater to have CLE than patients without GERD. Furthermore, segments with three centimeters or more showed eight more chances to have intestinal metaplasia, i.e. Barrett's esophagus.

The diagnosis of $\mathrm{BE}$ is still a conundrum once there are controversies on its proper definition and diagnostic criteria. CLE can present three types of epithelium: cardiac, oxyntic-cardiac and intestinal metaplasia ${ }^{(5)}$. There is a general agreement among GI societies all over the world that is essential the endoscopic identification of CLE for the diagnosis of BE. The main differences are related to the requirement for the presence of intestinal metaplasia with goblet cells in biopsies from CLE. The American Gastroenterology Association (AGA) states that only intestinal metaplasia (with goblet cells) represents $\mathrm{BE}$ and predisposes to adenocarcinoma ${ }^{(17)}$. In contrast, the British Society of Gastroenterology defines BE as any metaplastic columnar epithelium identified by endoscopy and confirmed by histology above the gastroesophageal junction, equal or greater than $1 \mathrm{~cm}^{(1)}$. In both recommendations, to obtain biopsies is essential for the diagnosis but biopsy sampling has some flaws, mainly in the short segments, as we could see in some patients with suspected short segments who presented squamous epithelium in the histopathological exam. Otherwise, a biopsy from the vicinity of the esophagogastric junction with intestinal metaplasia could either represent BE or intestinal metaplasia of the proximal gastric mucosa. Due to this uncertainty and to the retrospective nature of this study it is not possible affirm if some intestinal metaplasia founded in short segments were targeted appropriately and therefore, they could be from the stomach.

Patients with CLE without intestinal metaplasia seems to have a lower risk for cancer progression than patients with intestinal metaplasia, but their risk is greater than the general population ${ }^{(3,6)}$. Furthermore, the risk of cancer among the patients with a shortsegment is lesser than for patients with long-segment ${ }^{(6)}$. Our findings show that fundic epithelium, oxyntic-cardiac epithelium and columnar epithelium without goblet cells were much more frequent in short-segment than in long-segment. Whether the biopsies came from the esophagus, they represent a very low risk for cancerization, but it could also be possible that some of those samples could come from the stomach, as it was demonstrated elsewhere. In this last case, their meaning does not represent any risk ${ }^{(20)}$. This point reinforces AGA position of not recommending the term Barrett's Esophagus for patients with CLE with no intestinal metaplasia ${ }^{(18)}$.

This study has some limitation as for its retrospective design, which could introduce some bias in the data. Another potential bias, already mentioned, is the probability of error sampling for biopsies, mainly in short segments. It is possible that some biopsies came from gastric mucosa and not from the esophagus. The highlight of this study is its large sample and the survey period. To the best of our knowledge, it's the larger sample which accessed the prevalence of CLE and BE in Brazil. 
In conclusion, this study demonstrated the global frequency of CLE was $1.7 \%$, and when the approach is narrowed to patients with GERD, it turns out to be $5.6 \%$. BE defined by the presence of intestinal metaplasia with goblet cell presented an overall prevalence of $0.7 \%$ and $2.7 \%$ in patients with GERD. GERD patients were identified with a risk 30 -folds greater to present CLE than patients without GERD. Patients with a long segment of CLE had an increased risk of eight folds to have BE. Long BE counted for $0.3 \%$ of the population sample and $1.1 \%$ of GERD patients. Screening for $\mathrm{BE}$ in the general population in a region where the prevalence of adenocarcinoma of the esophagus is a rare event could be not worthwhile. The follow-up of these patients with long-segment of $\mathrm{BE}$ will reveal if the surveillance is cost- effective. Moreover, more research is needed to understand the pathogenesis of CLE and elucidate the progression from gastric metaplasia to intestinal phenotype - Barrett's esophagus - associated with cancer.

\section{Authors' contributions}

Fagundes RB and De Carli DM designed the research protocol. Araujo AF conducted the process for IRB permission and collected the data. Fagundes RB, analyzed the data and wrote the manuscript. All authors read and approved the manuscript final version.

De Carli DM, Araujo AF, Fagundes RB. Baixa prevalência de esôfago de Barrett em área de risco para câncer esofágico no Sul do Brasil. Arq Gastroenterol. 2017;54(4):305-7.

RESUMO - Contexto - Esôfago de Barrett, complicação da doença do refluxo gastroesofágico (DRGE), é lesão precursora do adenocarcinoma esofágico. O adenocarcinoma esofágico apresenta incidência crescente principalmente no ocidente. O estado do Rio Grande do Sul apresenta as taxas mais altas de câncer esofágico no Brasil, porém com baixa prevalência de adenocarcinoma. Objetivo - Investigar a prevalência de esôfago de Barrett em pacientes submetidos a endoscopia digestiva alta nos últimos 5 anos. Métodos - Revisão de prontuários dos pacientes submetidos a endoscopia digestiva alta entre 2011 e 2015. Registrados dados demográficos, sintomas de DRGE, achados endoscópicos, extensão e diagnóstico histológico de epitelização colunar do esôfago. A significância entre as variáveis foi acessada pelos testes do qui-quadrado e exato de Fisher com IC95\%. Resultados - Foram incluídos 5996 pacientes. Identificamos 1769 (30\%) com sintomas de DRGE ou esofagite e 107 (1,8\%) com epitelização colunar. À exceção de oito pacientes com epitelização colunar, os demais apresentavam sintomas de DRGE ou esofagite. Esôfago de Barrett definido pela presença de metaplasia intestinal ocorreu em 47 pacientes; 20 (43\%) com segmentos acima de $3 \mathrm{~cm}$ e em 27 (57\%) com segmentos menores. A prevalência global de esôfago de Barrett foi $0,7 \%$ e em pacientes com DRGE foi 2,7\%. A razão de chances para a ocorrência de epitelização colunar em pacientes com DRGE foi $30($ IC $95 \%=15,37-63,34)$ e para a ocorrência de metaplasia intestinal em segmentos longos foi 8 (IC95\%=2,83-23,21). Conclusão - Pacientes com DRGE apresentaram risco 30 vezes maior que pacientes sem DRGE para a ocorrência de epitelização colunar. O risco de ocorrência de esôfago de Barrett em segmentos longos foi oito vezes maior. A prevalência global de esôfago de Barrett foi $0,7 \%$. Em pacientes com DRGE a prevalência foi 2,7\%. Segmentos longos de esôfago de Barrett representaram globalmente $0,3 \%$ e em pacientes com DRGE $1,1 \%$.

DESCRITORES - Esôfago de Barrett. Células epiteliais. Neoplasias esofágicas. Neoplasias intestinais. Refluxo gastroesofágico.

\section{REFERENCES}

1. Aida J, Vieth M, Shepherd NA, Ell C, May A, Neuhaus H, et al. Is carcinoma in columnar-lined esophagus always located adjacent to intestinal metaplasia? A histopathologic assessment. Am J Surg Pathol. 2015;39:188-96.

2. Andreolo NA, Michelino MU, Brandalise NA, Lopes LR, Trevisan MA, Leonardi MS. Incidence and epidemiology of Barrett's epithelium at the Gastrocentro-UNICAMP. Arch Gastroentrol. 1997;34:22-6.

3. Chandrasoma P, Wijetunge S, DeMeester S, Ma Y, Hagen J, Zamis L, et al. Columnar-lined esophagus without intestinal metaplasia has no proven risk of adenocarcinoma. Am J Surg Pathol. 2012;36:1-7.

4. Chandrasoma P, Wijetunge S, Demeester SR, Hagen J, Demeester TR. The histologic squamo-oxyntic gap: an accurate and reproducible diagnostic marker of gastroesophageal reflux disease. Am J Surg Pathol. 2010;34:1574-81.

5. Chandrasoma PT, Der R, Dalton P, Kobayashi G, Ma Y, Peters J, et al. Distribution and significance of epithelial types in columnar-lined esophagus. Am J Surg Pathol. 2001;25:1188-93.

6. Desai TK, Krishnan K, Samala N, Singh J, Cluley J, Perla S, et al. The incidence of oesophageal adenocarcinoma in non-dysplastic Barrett's oesophagus: a meta-analysis. Gut. 2012;61:970-6.

7. Dietz J, Meurer L, Maffazzoni DR, Furtado AD, Prolla JC. Intestinal metaplasia in the distal esophagus and correlation with symptoms of gastroesophageal reflux disease. Dis Esophagus. 2003;16:29-32.

8. Dubecz A, Solymosi N, Stadlhuber RJ, Schweigert M, Stein HJ, Peters JH. Does the Incidence of Adenocarcinoma of the Esophagus and Gastric Cardia Continue to Rise in the Twenty-First Century?-a SEER Database Analysis. J Gastrointest Surg. 2013.

9. Fagundes RB, de Carli D, Xaubet RV, Cantarelli JC. Unchanging pattern of prevalence of esophageal cancer, overall and by histological subtype, in the endoscopy service of the main referral hospital in the central region of Rio Grande do Sul State, in Southern Brazil. Dis Esophagus. 2016;29:603-6.

10. Fan X, Snyder N. Prevalence of Barrett's esophagus in patients with or without GERD symptoms: role of race, age, and gender. Dig Dis Sci. 2009;54:572-7.
11. Fitzgerald RC, di Pietro M, Ragunath K, Ang Y, Kang JY, Watson P, et al. British Society of Gastroenterology guidelines on the diagnosis and management of Barrett's oesophagus. Gut. 2014;63:7-42.

12. Freitas MC, Moretzsohn LD, Coelho LGVC. Prevalência do esôfago de Barrett em indivíduos sem sintomas típicos da doença por refluxo gastroesofágico. Arq Gastroenterol. 2008;45:46-9.

13. Goldblum JR. Current issues in Barrett's esophagus and Barrett's-related dysplasia. Mod Pathol. 2015;28 Suppl 1:S1-6.

14. Kusano C, Gotoda T, Khor CJ, Katai H, Kato H, Taniguchi H, et al. Changing trends in the proportion of adenocarcinoma of the esophagogastric junction in a large tertiary referral center in Japan. J Gastroenterol Hepatol. 2008;23:1662-5.

15. Nader F, da Costa JS, Nader GA, Motta GL. [Prevalence of heartburn in Pelotas, RS, Brasil: population-based study]. Arq Gastroenterol. 2003;40:31-4.

16. Ronkainen J, Aro P, Storskrubb T, Johansson SE, Lind T, Bolling-Sternevald E, et al. Prevalence of Barrett's esophagus in the general population: an endoscopic study. Gastroenterology. 2005;129:1825-31.

17. Spechler SJ, Sharma P, Souza RF, Inadomi JM, Shaheen NJ. American Gastroenterological Association medical position statement on the management of Barrett's esophagus. Gastroenterology. 2011;140:1084-91.

18. Spechler SJ, Souza RF. Barrett's esophagus. N Engl J Med. 2014;371:836-45.

19. Vargas Cárdenas G. [Barrett's esophagus: prevalence and risk factors in the National Hospital Arzobispo Loayza in Lima-Peru]. Rev Gastroenterol Peru. 2010;30:284-304

20. Westerhoff M, Hovan L, Lee C, Hart J. Effects of dropping the requirement for goblet cells from the diagnosis of Barrett's esophagus. Clin Gastroenterol Hepatol. 2012;10:1232-6.

21. Whiteman DC, Kendall BJ. Barrett's oesophagus: epidemiology, diagnosis and clinical management. Med J Aust. 2016;205:317-24.

22. Xie SH, Lagergren J. Time trends in the incidence of oesophageal cancer in Asia: Variations across populations and histological types. Cancer Epidemiol. 2016;44:71-6. 